\title{
Optimization of Contents of Three Raw Clay Materials in Formulation of a Porcelain
}

\author{
Youssouf Sawadogo ${ }^{1}$, Moustapha Sawadogo ${ }^{1}$, Moussa Ouédraogo ${ }^{1}$, Mohamed Seynou ${ }^{1}$, \\ Gisèle Lecomte-Nana², Philippe Blanchart², Moussa Gomina ${ }^{3}$, Lamine Zerbo1* \\ ${ }^{1}$ Laboratory of Molecular Chemistry and Materials (LC2M), University Joseph KI-ZERBO, Burkina Faso \\ ${ }^{2}$ Institute of Research in Ceramic (IRCER), UMR-CNRS, European Ceramic Center, Limoges, France \\ ${ }^{3}$ Laboratory of Cristallography and Material Sciences (CRISMAT), UMR National Graduate School of Engineering of Caen \\ (ENSICAEN), Caen, France \\ Email: *lamine_zerbo@yahoo.fr
}

How to cite this paper: Sawadogo, Y., Sawadogo, M., Ouédraogo, M., Seynou, M., Lecomte-Nana, G., Blanchart, P., Gomina, M. and Zerbo, L. (2022) Optimization of Contents of Three Raw Clay Materials in Formulation of a Porcelain. Journal of Materials Science and Chemical Engineering, 10, 41-58.

https://doi.org/10.4236/msce.2022.101003

Received: November 28, 2021

Accepted: January 21, 2022

Published: January 24, 2022

Copyright $\odot 2022$ by author(s) and Scientific Research Publishing Inc. This work is licensed under the Creative Commons Attribution International License (CC BY 4.0).

http://creativecommons.org/licenses/by/4.0/

\begin{abstract}
Formulation of traditional hard porcelain generally requires 50\% kaolin, 25\% silica and 25\% feldspar. Four porcelains formulation using the casting method, were prepared with different percentages of kaolinitic clay, sand and pegmatite referenced respectively NONG, SAB and PEG. The physico-chemical, mechanical and mineralogical characteristics were evaluated on specimens formulated and sintered at different temperatures from $1200^{\circ} \mathrm{C}$ to $1300^{\circ} \mathrm{C}$. X-ray diffraction has revealed the presence of mullite and quartz as essentially crystalline phases. The specimen formulated with 55\% NONG, 25\% PEG and 20\% $\mathrm{SAB}$ and sintered at $1240^{\circ} \mathrm{C}$ gives better performance (water absorption: $0.17 \%$, density: 2.42 , open porosity: $0.42 \%$ and flexural strength: $53.54 \mathrm{MPa}$ ).
\end{abstract}

\section{Keywords}

Raw Minerals, Porcelain, Characterization, Chemical Durability and Phase Transformations

\section{Introduction}

Most ceramics are multiphase materials that contain both crystalline phases and vitreous phases. But can also be observed millimetric crystal agglomerates with a very porous microstructure or fine-grained polycrystals ( $<10$ microns) without vitreous phases and very low porosity. In addition to chemical nature of compound, it is microstructure of material (size, grain shape, rate and types of porosity, phase distribution) that controls their properties. In this present work, we study the impact of powder contents of different raw materials used in produc- 
tion of porcelain. Porcelain is a ceramic product formulated from a mixture of three materials: clay and kaolin; quartz; feldspar. It is a very compact, vitrified product with low porosity. Porcelain is an aesthetic product and generally white, semi-transparent, waterproof, resistant to strong bases and abrasives. In porcelain bodies, during heat treatment, the major component kaolinite $\left(\left(\mathrm{Al}_{2} \mathrm{Si}_{2} \mathrm{O}_{5}\right)-(\mathrm{OH})_{4}\right)$ transforms to metakaolinite at $550^{\circ} \mathrm{C}-600^{\circ} \mathrm{C}$, which is a dehydrated metastable amorphous structure. Then, at $950^{\circ} \mathrm{C}-1000^{\circ} \mathrm{C}$, the latter transforms to a spinel structure and amorphous silica. At the same time, feldspar grains react with sili$\mathrm{ca}$ and kaolinite phases to form a viscous liquid phase at $990^{\circ} \mathrm{C}$. In this stage, quartz grains begin to dissolve into the liquid phase. Above $1100^{\circ} \mathrm{C}$, spinel transforms to primary mullite and silica. Above $1200^{\circ} \mathrm{C}$ secondary mullite crystals nucleate and grow, following the reaction of clay with feldspar relicts [1]. Today porcelain is produced in many countries and its technology is well known and described in various manuals and documents [2]. Porcelain materials are used as the main tools of the housewife. This strong demand linked to their properties justifies the interest that researchers have in these materials. In this study, we evaluate the impact of the variation in the contents of these raw materials used on the physicochemical properties of the parts produced such as water absorption, porosity, density, mineralogy, flexural strength of rupture and behavior in the face of chemical agents.

\section{Materials and Methods}

\subsection{Materials}

Samples used in this work are a kaolinitic clay, a pegmatite and sand. These samples are referenced respectively NONG, PEG and SAB and come from two regions of Burkina Faso: the Haut Bassin region and the North region. Nongfairé is a locality located about forty kilometers from Ouahigouya (about $39 \mathrm{~km}$ south-east of Ouahigouya) in the rural commune of Oula. NONG is sampled from the Nongfä̈ré site at geographic coordinates $2^{\circ} 09^{\prime}$ West Longitude and $13^{\circ} 29^{\prime}$ North Latitude. PEG and SAB are collected respectively in the deposits of Kotédougou and Borodougou and the geographical coordinates respectively $4^{\circ} 4^{\prime}$ West, $11^{\circ} 7^{\prime}$ North and $11^{\circ} 10^{\prime}$ North, $4^{\circ} 17^{\prime}$ West [3].

\subsection{Formulation}

To optimize NONG, PEG and SAB contents, several types of specimens referenced $F_{1}, F_{2}, F_{3}$ and $F_{4}$ depending on the composition of the slip (Table 1) were formulated. Each mixture is composed of powder ground to a particle size of less than $100 \mu \mathrm{m}$. To ensure good dispersion of slip, $0.5 \mathrm{wt} \%$ of carbonate sodium (deflocculant) were used [4]. $1000 \mathrm{~g}$ of mixture of raw materials, $5 \mathrm{~g}$ of sodium carbonate, water and pebbles are set in motion in a jar for 10 minutes by two turners at a speed of 75 revolutions per minute in order to have a homogeneous mixture. Mixing is then carried out by shearing the grains of powder between the rollers. Mixture called slip is then poured into plaster molds. The role of the 
Table 1. Compositions of slurries of raw materials.

\begin{tabular}{|c|c|c|c|c|c|}
\hline \multicolumn{2}{|c|}{ References of specimens } & $\mathrm{F}_{1}$ & $\mathrm{~F}_{2}$ & $\mathrm{~F}_{3}$ & $\mathrm{~F}_{4}$ \\
\hline \multirow{3}{*}{ Raw material composition (wt\%) } & Clay (NONG) & 50 & 55 & 60 & 65 \\
\hline & Pegmatite (PEG) & 25 & 25 & 20 & 20 \\
\hline & Sand (SAB) & 25 & 20 & 20 & 15 \\
\hline \multicolumn{2}{|c|}{ Water content (wt\%) } & 50 & 55 & 60 & 65 \\
\hline
\end{tabular}

plaster mold is to absorb unbound water thanks to its micropores and this makes it possible to obtain specimens cookies with good resistance to flooding. Water (content 1: 2 in dry matter) used for the preparation of the slurry is from the Ouagadougou urban network supplied by the National Office for Water and Sanitation (ONEA) of Burkina Faso. After drying, the specimens were fired in a Naberthem P330 brand oven. In order to obtain partially vitrified products, all the specimens were sintered at temperatures greater than or equal to $1200^{\circ} \mathrm{C}$ with steps of $20^{\circ} \mathrm{C}$. The average heating rate is $10^{\circ} \mathrm{C} / \mathrm{min}$ up to the final given temperature $\left(1200^{\circ} \mathrm{C}, 1220^{\circ} \mathrm{C}, 1240^{\circ} \mathrm{C}, 1280^{\circ} \mathrm{C}\right.$ and $\left.1300^{\circ} \mathrm{C}\right)$ is reached, at which the samples were treated for $1 \mathrm{~h}$ in electrical furnace with air atmosphere.

At end of the baking level, the cooling takes place freely to room temperature thanks to the oven's integrated cooling system. Fired specimens are recovered for testing in order to assess their qualities. Figure 1 presents diagram of heat treatment.

\subsection{Experimental Methods}

Chemical analyses of the samples were carried out by X-ray fluorescence and the loss of ignition was obtained with a Nabertherm C250 type furnace at $1000^{\circ} \mathrm{C}$ at a rate of $10^{\circ} \mathrm{C} / \mathrm{min}$ and a step of 2 hours.

Viscosity of the slips was determined using a Brookfield Model DV-I + type viscometer measuring device and calibrate on serie of model LV. The LV3 pin of the device guide, selected according to the device instructions, is immersed in a $500 \mathrm{~mL}$ beaker containing the slip. The spring torsion constant (TK) of the viscometer is 0.09373 and the spindle multiplyer constant (SMC) is 128 . Immersion is done with care in order to avoid trapping air bubbles under the disc of the spindle, then it is immersed, fixed to the head. Before starting the test, enter the spindle code as well as the rotation speed set at $0.5 \mathrm{rpm}$ and so as to have a sufficient torque value $(>20 \%)$ to obtain viscosity with an acceptable error. The spinel used is $n^{\circ} 3 \mathrm{~S} 63$. Viscosity value is given in centipoise $(\mathrm{cP})$ and the temperature in ${ }^{\circ} \mathrm{C}$. All values were read after 5 minutes of immersion of the spindle.

Density shows the mineral content of the slip and the amount of processing water. A volume ( $V$ ) of slip is weighed $\left(M_{b}\right)$ in a beaker, then the empty beaker is weighed $\left(M_{v}\right)$ using a balance. Value of the density is determined by following Equation (1): 


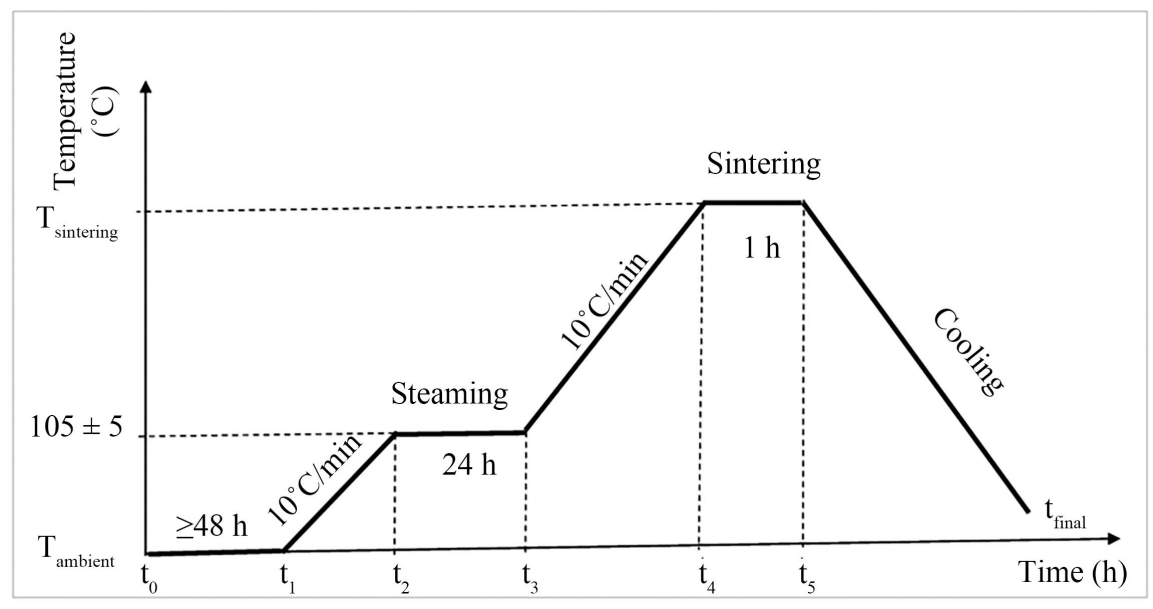

Figure 1. Qualitative diagram of heat treatment of specimens.

$$
d=\frac{M_{b}-M_{v}}{V}
$$

$M_{b}$ : mass of the beaker containing the slip (g);

$M_{r}$ : mass of the empty beaker $(\mathrm{g})$;

$V$ : volume of the slip in the beaker.

Determination of the percentage of passers-by on a $40 \mu \mathrm{m}$ sieve of the slurries after the density calculation is very important and must be carried out. A quantity of the (dry) powder mixture $M_{i}(\mathrm{~g})$ is weighed, it is then passed through the $40 \mu \mathrm{m}$ sieve (wet sieving). The residue is dried in an oven at $105^{\circ} \mathrm{C}$ and its mass $M_{r}(\mathrm{~g})$ is weighed. The percentage of passers-by is calculated using the formula of Equation (2):

$$
\% \text { passers }- \text { by }_{40 \mu \mathrm{m}}=\frac{M_{i}-M_{r}}{M_{i}} \times 100
$$

$\mathrm{pH}$ of the slurries was determined after each shaking of the suspensions in order to avoid the phenomenon of thixotropy using a branded $\mathrm{pH}$ meter (PCE-PHD 1) fitted with a combined electrode.

Mass loss of ceramic articles due to the evaporation of volatiles, chemically bound water, organic compounds and carbons, is determined by the equation below in accordance with ASTM D7348-08 [5].

Shrinkage is a reduction in the dimensions of the material after drying or under the action of heat. The dimensions of the material are measured before and after sintering (heat treatment). Difference between these dimensions of the material gives the linear shrinkage. Equation (3) below gives the expression of the shrinkage [6]:

$$
R(\%)=\frac{L_{i}-L_{f}}{L_{i}} \times 100
$$

With: $R(\%)$ : shrinkage rate; $L_{\dot{i}}$ initial length of the material before drying; $L_{\dot{f}}$ final length of the material after drying.

The water absorption (E) of the firing test pieces was determined according to 
ISO 10545-3 [7]. A mass $m_{0}$ of each sintered specimen is immersed in boiling water for two hours. After four hours of cooling, the new mass $m_{f}$ of the wet specimen is weighed ( $\pm 0.001 \mathrm{~g}$ precision). The difference in mass gives the mass of water absorbed by the specimen during this time. The water absorption is evaluated according to Equation (4):

$$
E(\%)=\frac{\left(m_{f}-m_{0}\right)}{m_{0}} \times 100
$$

Bulk density of specimens has been determined in accordance with the ISO 10545-3 [7]. It was determined using Equations (5) and (6) [3]. The test consists in successively measuring the mass and the volume of the sample. The volume is deduced from three weighings, one of which is made after immersing the sample in water. The sample is weighed $(m)$ and waxed immediately afterwards. The waxed sample is weighed $\left(m_{p}\right)$ in the open air, then placed in a basket suspended from the stirrup and immersed in order to be weighed $\left(m_{p}^{\prime}\right)$ hydrostatically.

$$
\begin{gathered}
\rho=m / v \\
\text { With: } v=\frac{\left(m_{p}-m_{p}^{\prime}\right)}{\rho_{w}}-\frac{\left(m_{p}-m\right)}{\rho_{p}}
\end{gathered}
$$

where under the same conditions of temperature and pressure: $\rho_{w}$ density of water $\left(1000 \mathrm{~kg} / \mathrm{m}^{3}\right) ; \rho_{p}$ density of paraffin $\left(880 \mathrm{~kg} / \mathrm{m}^{3}\right) ; m$ the mass of the sample; $m_{p}$ the mass of the paraffinic sample and $m_{p}^{\prime}$ the hydrostatic mass of the waxed sample.

Chemical properties are evaluated based on the ability of a material to resist acids, bases and salt solutions, which cause exchange reactions and destroy the material. These tests are carried out according to the ISO 10545-13 standard [8].

Principle is to evaluate the change of a specimen under the action of a test solution based on the observation of the degree of surface change after the test.

The solutions used for the tests are:

- Ammonium chloride, $\mathrm{NH}_{4} \mathrm{Cl}$, concentration in solution of $100 \mathrm{~g} / \mathrm{L}$;

- Hydrochloric acid $(\mathrm{HCl}), 3 \%$ and $18 \%$ by volume solutions, prepared from concentrated $\mathrm{HCl}(\rho=1.19 \mathrm{~g} / \mathrm{mL})$;

- Alkali (KOH), solutions with concentrations of $30 \mathrm{~g} / \mathrm{L}$ and $100 \mathrm{~g} / \mathrm{L}$.

Each sample is then weighed and examined with an optical microscope, in order to visually detect changes on the two half-faces of the submerged samples compared to the non-submerged half-surface [9]. Porcelains are classified according to Table 2 .

Flexural mechanical properties are obtained by three-point flexural tests with rectangular cross-section specimens. They were placed on two parallel supporting pin and the loading force is applied in the middle by means of a loading pin. The supporting and loading pins are mounted in the way to allow their free rotation about the axis parallel to the pin axis. The fracture strength was obtained with samples having width (W) egal to $9 \mathrm{~mm}$ and thickness (B) beteen 6 and 8 $\mathrm{mm}$. The 3-point bending device had a span $\mathrm{L}=40 \mathrm{~mm}$. The testing apparatus 
Table 2. Categories of test pieces according to their behavior in the face of chemical solutions.

\begin{tabular}{ccc}
\hline Observations & \multicolumn{2}{c}{ Test solutions and classification } \\
\cline { 2 - 3 } $\begin{array}{c}\text { No visible change } \\
\text { Visible change on the cut edge }\end{array}$ & $\mathrm{NH}_{4} \mathrm{Cl}(100 \mathrm{~g} / \mathrm{L}) \mathrm{HCl}(3 \%)$ et $\mathrm{KOH}(30 \mathrm{~g} / \mathrm{L}) \mathrm{HCl}(18 \%)$ et $\mathrm{KOH}(100 \mathrm{~g} / \mathrm{L})$ \\
\hline $\begin{array}{c}\text { Visible change on the cut and uncut edges and on } \\
\text { the workpiece surface }\end{array}$ & Class B & Class A \\
\hline
\end{tabular}

was an Instron type, equipped with a load cell of $10 \mathrm{kN}$ and the Bluehill 2 software. The crosshead speed was $1 \mathrm{~mm} / \mathrm{min}$. The Maximum load at failure $\left(F_{r}\right)$ was converted into fracture strength $\left(\sigma_{r}\right)$ using the usual relation (Equation (7)) that is valid for rectangular samples [10].

$$
\sigma_{r}=\frac{3}{2} \frac{L F_{r}}{B W^{2}}
$$

Mineralogical compositions were obtained by X-ray diffraction using Brüker D8 type diffractometer operating at $40 \mathrm{kV}-40 \mathrm{~mA}$ and using the monochromatic $\mathrm{CuK} \alpha$ radiation. The machine was driven by Diffracplus D software Version 2.2. The acquisition time was $60 \mathrm{~min}$. The diffractograms obtained were analyzed using QualX software, using the POWCOD database.

\section{Results}

\subsection{Chemical and Mineralogical Analysis of Raw Materials}

The chemical composition of the raw materials used is shown in Table 3. Data indicate that the clay and pegmatite are aluminosilicates. For NONG, the ratio $\mathrm{SiO}_{2} / \mathrm{Al}_{2} \mathrm{O}_{3}(\approx 1.73)$ is higher than that of pure kaolinite $(\approx 1.18)$, from the presence of free silica. The relatively high content of potassium oxide $\left(\% \mathrm{~K}_{2} \mathrm{O}=2.09\right)$ show the presence of micaceous phases (muscovite or illite). For PEG, a fairly high alkaline oxides content $\left(\% \mathrm{~K}_{2} \mathrm{O}+\% \mathrm{Na}_{2} \mathrm{O}=7.17\right)$ show the predominance of mixed feldspar minerals and mica phases. For $\mathrm{SAB}$, the strong predominance of silica results from quartz [3]. However, the low content of $\mathrm{Fe}_{2} \mathrm{O}_{3}$ make the samples very attractive raw materials for several industries [11].

The mineralogical characterization results showed that the clay NONG contains kaolinite (62\%), illite (18\%), quartz (17\%) and rutile (1\%). The pegmatite PEG contains albite (17\%), muscovite (44\%) and quartz (34\%). The sand SAB is mainly composed of quartz [3].

\subsection{Rheological Properties and Chemical Composition of Slurries}

To form ceramic components by slip casting, it is necessary to specify in the slurry formulation the types and amounts of carrier fluid, dispersant, $\mathrm{pH}$ modifier, and binder [12]. Some parameters of slip were evaluated in order to assess their influence on finished products. Thus, the flood particle size of the powders was $100 \mu \mathrm{m}$ for all the grades $\mathrm{F}_{1}, \mathrm{~F}_{2}, \mathrm{~F}_{3}$ and $\mathrm{F}_{4}$. After obtaining this slip, the particle size change in accordance with Table 4 . The shades are accompanied by the 
particle size values of the slip.

The slurries obtained are all basic $(\mathrm{pH}>10)$. Viscosities are measured with a torsion torque superior to $15 \%$ and are compriss between 55,000-75,000 cP. The rellatively high values (of order to $10^{3} \mathrm{cP}$ ) are due to use of sodium carbonate as defloculant. The evaluated densities are relatively high (1.5 - 1.75). More than $60 \%$ of the passers-by of slip are sizes inferior to $40 \mu \mathrm{m}$ and than more $85 \%$ are sizes inferior to $63 \mu \mathrm{m}$.

Chemical analysis of the different shades shows that $\mathrm{SiO}_{2} / \mathrm{Al}_{2} \mathrm{O}_{3}$ ratio decreases in the order of $\mathrm{F}_{1}$ to $\mathrm{F}_{4}$ while $\mathrm{K}_{2} \mathrm{O} / \mathrm{Na}_{2} \mathrm{O}$ ratio increases from 1.52 to 2.24 (Table 5). However, the percentages of alkaline oxide $\left(\% \mathrm{~K}_{2} \mathrm{O}+\% \mathrm{Na}_{2} \mathrm{O}\right)$ are higher for the shades $\mathrm{F}_{2}(3.23 \%)$ and $\mathrm{F}_{4}(3.11 \%)$ than for $\mathrm{F}_{1}(3.02 \%)$ et $\mathrm{F}_{3}(3.02 \%)$.

\subsection{Linear Shrinkage at Sintering and Bulk Density}

Linear shrinkage of porcelain specimens has a similar trend, as shown in Figure 2(a). Linear shrinkage of specimens increases continuously with increasing temperature and reaches the maximum value $(13.7 \%-15.6 \%)$, which corresponds well to their volumetric densification [13]. The shrinkage decreases with the content of sand in the sample. Note that linear shrinkage behaves differently below and above $1280^{\circ} \mathrm{C}$ for $\mathrm{F}_{2}$ and $\mathrm{F}_{3}$.

Table 3. Chemical composition of raw materials.

\begin{tabular}{ccccccccccc}
\hline Oxides & $\mathrm{SiO}_{2}$ & $\mathrm{Al}_{2} \mathrm{O}_{3}$ & $\mathrm{CaO}$ & $\mathrm{K}_{2} \mathrm{O}$ & $\mathrm{MgO}$ & $\mathrm{Na}_{2} \mathrm{O}$ & $\mathrm{TiO}_{2}$ & $\mathrm{Fe}_{2} \mathrm{O}_{3}$ & LOI $^{*}$ & Total \\
\hline NONG & 54.59 & 31.5 & 0.03 & 2.09 & 0.54 & 0.29 & 1.43 & 0.87 & 7.29 & 98.63 \\
PEG & 66.01 & 22.31 & 0.38 & 5.15 & 0.13 & 2.02 & 0.02 & 0.99 & 2.96 & 100.05 \\
SAB & 86.67 & 9.82 & 0.13 & 0.07 & 0.05 & 0.16 & 0.3 & 0.1 & 2.70 & 100 \\
\hline
\end{tabular}

${ }^{\star}$ LOI: Loss on Ignition at $1000^{\circ} \mathrm{C}$.

Table 4. Some characteristic parameters of the slip measured.

\begin{tabular}{|c|c|c|c|c|c|c|c|}
\hline \multirow[b]{2}{*}{ Grades } & \multicolumn{2}{|c|}{ Viscosity at $29.3^{\circ} \mathrm{C}$} & \multirow[b]{2}{*}{ Density } & \multirow{2}{*}{$\begin{array}{l}\mathrm{pH} \text { at } \\
25^{\circ} \mathrm{C}\end{array}$} & \multicolumn{3}{|c|}{ Passers (\%) } \\
\hline & $\begin{array}{c}\text { Viscosity } / 10^{3} \\
\text { (cP) }\end{array}$ & $\begin{array}{c}\text { Torsion } \\
\text { torque (\%) }\end{array}$ & & & $40 \mu \mathrm{m}$ & $63 \mu \mathrm{m}$ & $100 \mu \mathrm{m}$ \\
\hline $\mathrm{F}_{1}$ & $64.32 \pm 3$ & 30.04 & 1.72 & 10.57 & 87.91 & 93.96 & 100 \\
\hline $\mathrm{F}_{2}$ & $63.12 \pm 3$ & 27.10 & 1.60 & 10.26 & 69.37 & 86.88 & 100 \\
\hline$F_{3}$ & $73.14 \pm 3$ & 32.10 & 1.56 & 10.32 & 74.55 & 92.89 & 100 \\
\hline $\mathrm{F}_{4}$ & $59.04 \pm 3$ & 24.70 & 1.50 & 10.38 & 77.67 & 90.65 & 100 \\
\hline
\end{tabular}

Table 5. Chemical composition of grades.

\begin{tabular}{cccccccccc}
\hline Oxides & $\mathrm{SiO}_{2}$ & $\mathrm{Al}_{2} \mathrm{O}_{3}$ & $\mathrm{Fe}_{2} \mathrm{O}_{3}$ & $\mathrm{CaO}$ & $\mathrm{MgO}$ & $\mathrm{K}_{2} \mathrm{O}$ & $\mathrm{Na}_{2} \mathrm{O}$ & Total $\left(\mathrm{K}_{2} \mathrm{O}\right)\left(\mathrm{Na}_{2} \mathrm{O}\right)$ \\
\hline $\mathrm{F}_{1}$ & 69.91 & 17.9 & 0.74 & 0.73 & 0.31 & 1.82 & 1.2 & 92.6 & 1.52 \\
$\mathrm{~F}_{2}$ & 67.11 & 20.56 & 0.81 & 0 & 0.35 & 2.11 & 1.12 & 91.75 & 1.88 \\
$\mathrm{~F}_{3}$ & 67.05 & 20.91 & 0.79 & 0 & 0.37 & 2.03 & 0.99 & 91.79 & 2.05 \\
$\mathrm{~F}_{4}$ & 65.62 & 21.81 & 0.82 & 0 & 0.39 & 2.15 & 0.96 & 91.43 & 2.24 \\
\hline
\end{tabular}



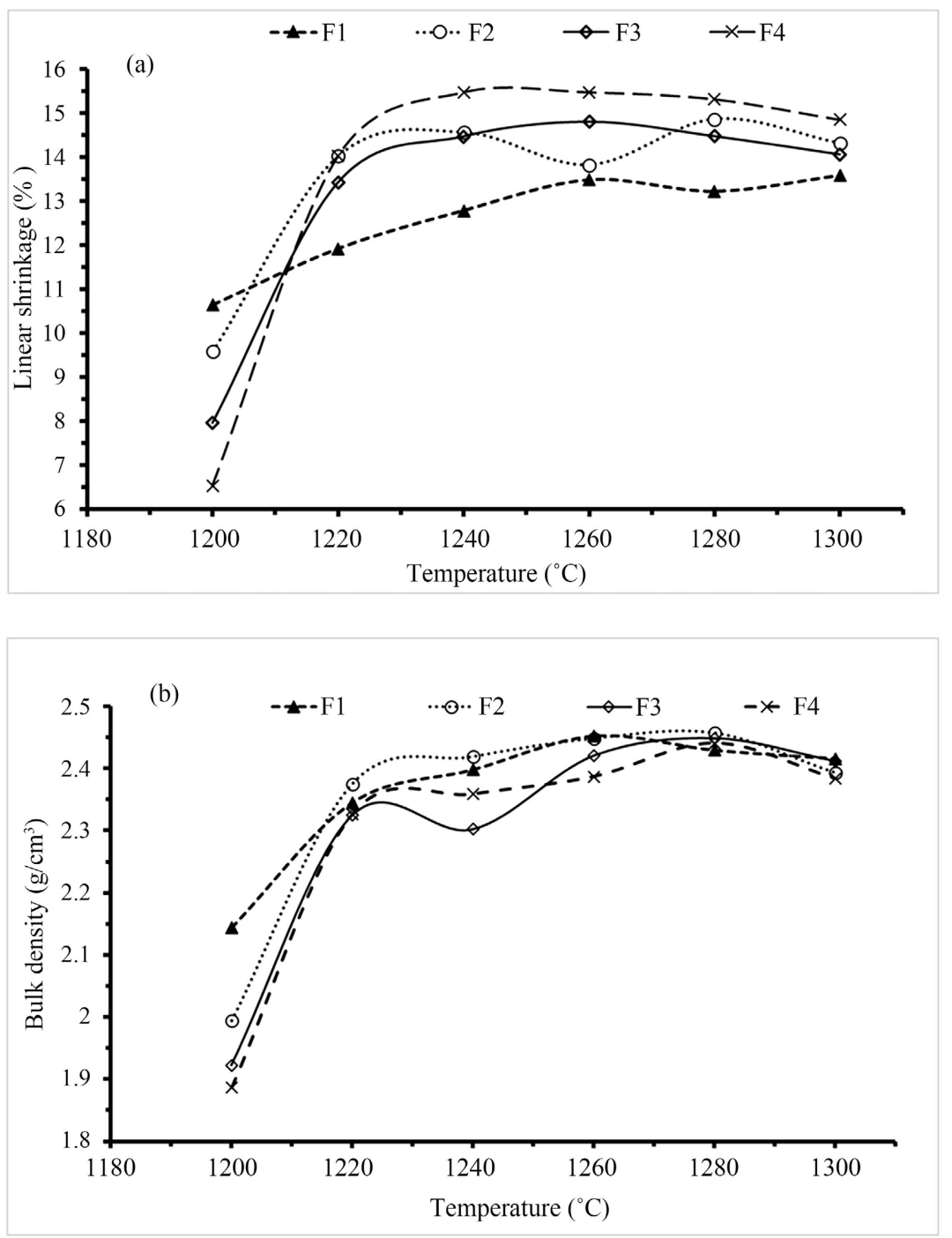

Figure 2. (a) Fired linear shrinkage evolution of sintered specimens as a function of temperature. (b) Bulk density of sintered specimens as a function of the temperature.

Bulk density is inversely proportional to porosity and water absorption. The bulk densitie of all shades increase with baking temperature and peak at the temperature of $1280^{\circ} \mathrm{C}$ as shown in Figure 2(b). From $1220^{\circ} \mathrm{C}$, the densities are increasingly high going from 2.3 to 2.5 [14]. They decrease above $1280^{\circ} \mathrm{C}$. This could be due to a strong production of vitreous phase thus leading to bloating [15]. Bloating is formation of voids or pores in the microstructure caused by expansion of gases trapped in these pores. Origin of gases trapped in the glass phase can be associated with loss of hydroxyl $(\mathrm{OH})$ from kaolinite crystals and the release of oxygen due to the decomposition of ferric oxide $\left(\mathrm{Fe}_{2} \mathrm{O}_{3}\right.$ to $\left.\mathrm{Fe}_{3} \mathrm{O}_{4}\right)$ [16]. Bloating also significantly affects electrical, mechanical and structural properties of porcelains. Generally, limit firing temperature and optimum vitreous phase are obtained when apparent porosity and water absorption reach their minimum values and the density of the body reaches the maximum [17]. Specimen $\mathrm{F}_{2}$ has a higher bulk density than other grades at $1220^{\circ} \mathrm{C}-1280^{\circ} \mathrm{C}$ temper- 
atures up to optimum densification. At $1200^{\circ} \mathrm{C}$, specimen $\mathrm{F}_{1}$ has a higher bulk density than $\mathrm{F}_{2}$. Linear shrinkage of specimen $\mathrm{F}_{2}$ once decreases at 1260 degree and can lead to material cracking. Specimen $F_{1}$ shows the lowest linear shrinkage.

\subsection{Water Absorption Rate and Porosity}

Water absorption and open porosity of all specimens decrease with increasing sintering temperature and reach a minimum at $1300^{\circ} \mathrm{C}$, as shown in Figure 3. This may occur explain by the melting of the feldspathic phases and the formation of a vitreous phase due to the increase in the firing temperature. According to Iqbal and Lee (2000) [18], feldspar melts at a lower temperature than other constituents in porcelain, and mixtures of clay and feldspar grains have lowest viscosity. Liquid resulting from the vitreous phase therefore fills the open pores of the microstructure and leads to densification of the body [19]. Figure 3(a) further indicates that $\mathrm{F}_{2}$ and $\mathrm{F}_{4}$ achieved vitrification with $0.17 \%$ water absorption at $1240^{\circ} \mathrm{C}$ compared to $0.09 \%$ at $1260^{\circ} \mathrm{C}$ for $\mathrm{F}_{1}$ and $\mathrm{F}_{3}$. Same phenomenon of glass mobility is also observed in the case of glazes containing $\mathrm{K}_{2} \mathrm{O}$ and $\mathrm{Na}_{2} \mathrm{O}$ during firing [20]. Porosity (Figure 3(b)) also decreases with increasing sintering temperature due to the formation of a vitreous phase mainly derived from pegmatite. This liquid phase is partly the result of the transformation of plastic minerals from the raw material such as kaolinite. It is formed by reaction between free silica, alumina and alkalis according to ternary system $\mathrm{SiO}_{2}-\mathrm{Al}_{2} \mathrm{O}_{3}-\mathrm{K}_{2} \mathrm{O}$ [21] [22]. Increase in temperature leads to an increase in the amount of liquid phase and a decrease in viscosity of liquid phase and fills the pores of the body. Therefore, porosity decreases [17]. Pores are considered intrinsic defects which may be the predominant factor in deterioration of strength [23]. Water absorption and porosity of specimens $\mathrm{F}_{1}$ et $\mathrm{F}_{3}$ keep constant values between $1220^{\circ} \mathrm{C}$ and $1240^{\circ} \mathrm{C}$ at opposite $\mathrm{F}_{2}$ et $\mathrm{F}_{4}$ that increase betwen $1220^{\circ} \mathrm{C}$ and $1260^{\circ} \mathrm{C}$. Optimum quantities of liquid phases are obtained from $1240^{\circ} \mathrm{C}$ for the specimens $\mathrm{F}_{2}$ and $\mathrm{F}_{4}$ and from $1260^{\circ} \mathrm{C}$ for $\mathrm{F}_{1}$ and $\mathrm{F}_{3}$. This difference of $20^{\circ} \mathrm{C}$ is of great technological importance to manufacturers of vitreous in order to save thermal energy.

\subsection{Mechanical Strength of Specimens}

Flexural strength (Figure 4) of all samples increases with increasing sintering temperature. Maximum flexural stress values meet commercial strength specification of porcelain (>35 MPa) [24]. Usually, maximum flexural strength develops in a porcelain specimen as porosity decreases and tends towards zero [25]. During sintering process, a liquid phase forms at the grain boundaries, amount of which depends on the increase in the sintering temperature. It results in part from transformation of plastic minerals such as kaolinite. Indeed, with the increase in the NONG clay content, quantity of plastic and melting minerals increases and therefore the liquid phase becomes more important. This phase is largely responsible for mechanical resistance of the sintered products [9]. In- 
creasing the amount of liquid phase at higher temperature negatively affects mechanical strength [15]. Flexural strength increases with increasing bulk density. Grade $\mathrm{F}_{2}$ has the highest mechanical resistance values $\left(53.50 \mathrm{MPa}\right.$ at $\left.1240^{\circ} \mathrm{C}\right)$ of all grades. This evolution has also been observed by S. K. Das and K. Dana for triaxial porcelain compositions [26].
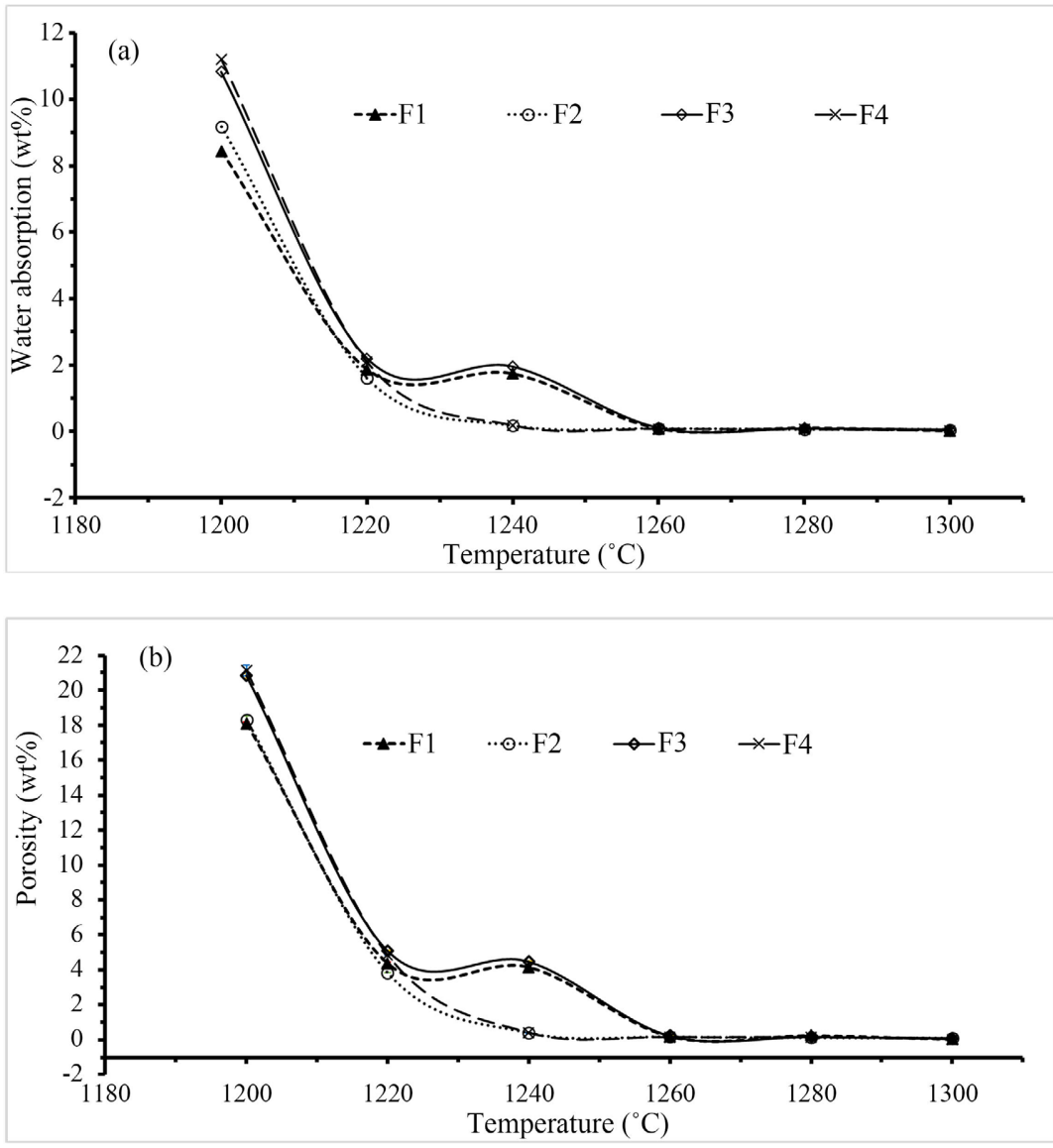

Figure 3. (a) Variation in water absorption of sintered specimens as a function of the temperature. (b) Evolution of the porosity of sintered specimens as a function of the temperature.

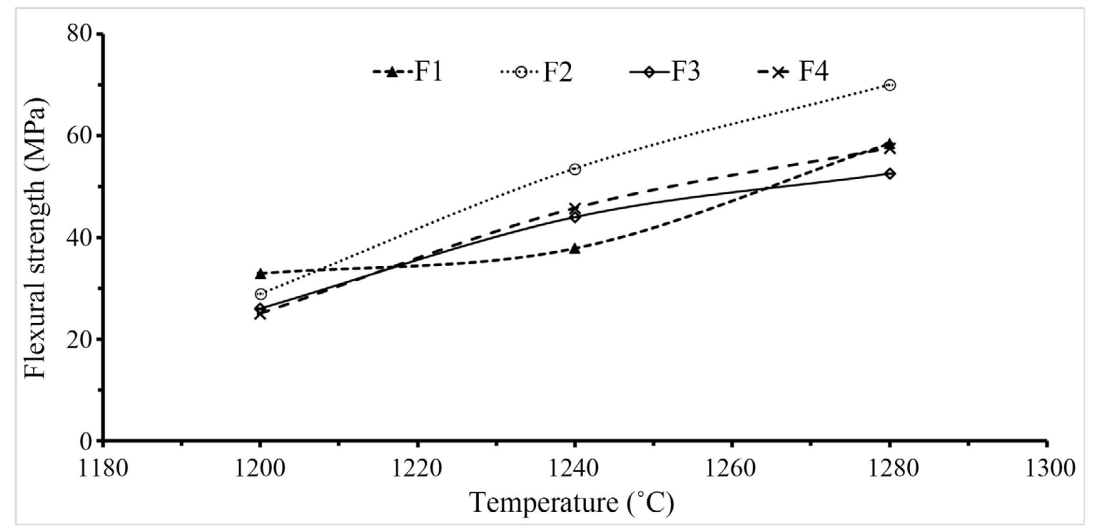

Figure 4. Variation of the strength at ruptureof sintered specimens as a function of the temperature. 


\subsection{Mineralogy and Microstructure}

XRD of all samples $\left(\mathrm{F}_{1}, \mathrm{~F}_{2}, \mathrm{~F}_{3}\right.$ and $\left.\mathrm{F}_{4}\right)$ sintered at $1240^{\circ} \mathrm{C}$ in Figure 5, shows that samples are virtually identical with regard to phases and amounts of constituents. Quartz and mullite are main crystal phases identified in all samples. Mullite is a crystalline phase of great technological importance due to its excellent technical properties, such as: low expansion and thermal conductivity $\left(\sim 4.5 \times 10^{-6}{ }^{\circ} \mathrm{C}^{-1}\right.$ and 6 $\mathrm{kcal} \cdot \mathrm{m}^{-1} \cdot \mathrm{h}^{-1} \cdot{ }^{\circ} \mathrm{C}^{-1}$ at $20^{\circ} \mathrm{C}$, respectively), and appropriate fracture strength and toughness ( 200 MPa y $\sim 2.5 \mathrm{MPa} \cdot \mathrm{m}^{1 / 2}$, respectively). In addition, it features high creep resistance, corrosion stability and thermal stability. All these features currently make mullite to be, probably, one of the most important phases in traditional and advanced ceramic [27]. Figure 6 shows that at higher firing temperatures $\left(\geq 1240^{\circ} \mathrm{C}\right)$ glass content increased at the expense of quartz in $\mathrm{F}_{2}$. Mullite peaks increase as the firing temperature increases. Quartz peaks, on the other hand, subside and gradually decrease with increasing temperature. This result suggests that dissolution of quartz can occur over a greater range of firing temperature.

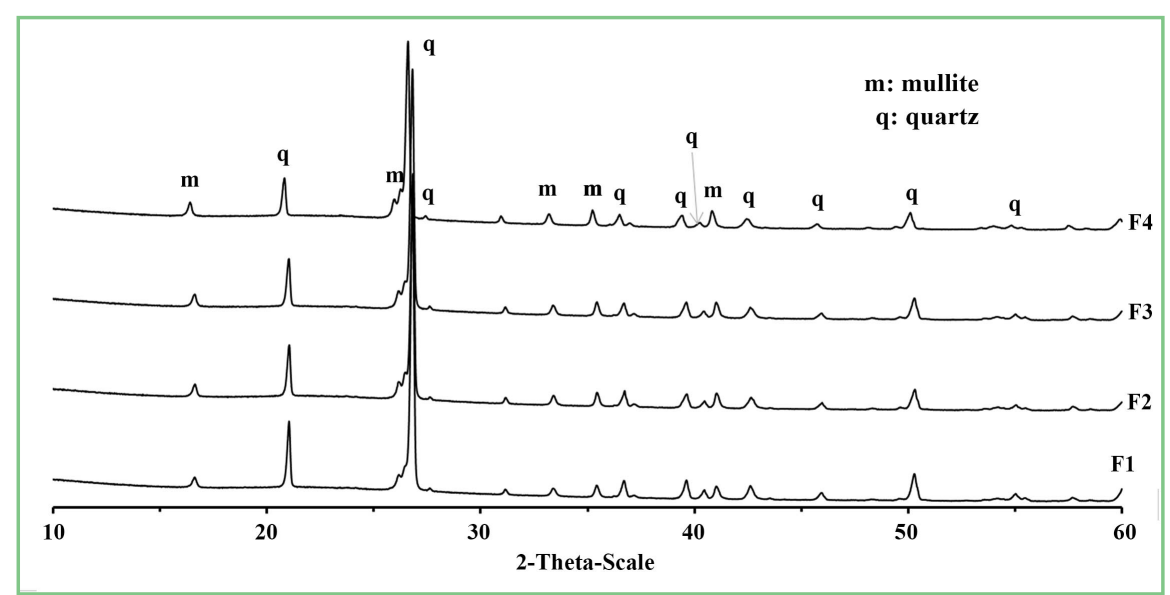

Figure 5. Diffractograms of the powders of the sintered specimens at $1240^{\circ} \mathrm{C}$.

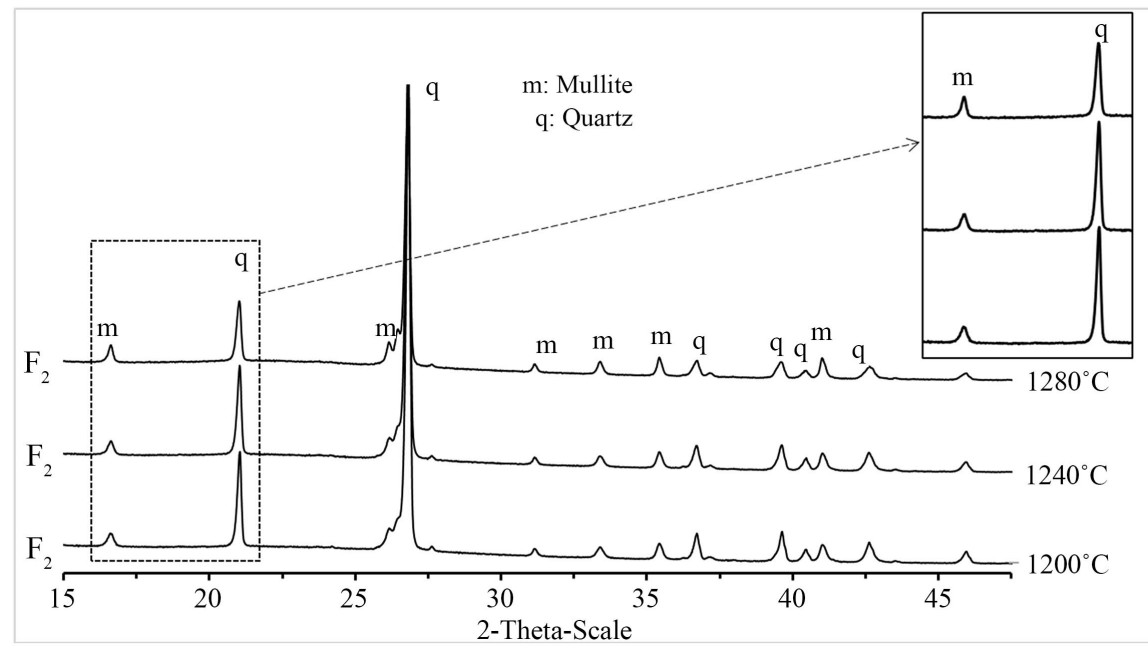

Figure 6. Diffractograms of the powders of the $\mathrm{F}_{2}$ test specimen sintered at different temperatures. 


\subsection{Chemical Durability}

Chemical durability is a principal property requirement of ceramics for intra-oral use, since dental prostheses must resist degradation in the presence of a wide range of solutions of variable $\mathrm{pH}$ [28]. A quantitative test was performed to predict the long-term behavior of specimens, in particular to obtain information on rate of material removal. Small variations in mass after chemical attack are observed and shown in Figure 7. Specimens fired at $1200^{\circ} \mathrm{C}$ suffered mass losses with all the chemical solutions used. Greatest loss in mass (1.2\%) was observed on the same specimens with the concentrated sodium hydroxide solution. These losses can be explained by the high porosity of these test pieces. These variations are also due to the presence (in small quantities) of certain metal oxides $\left(\mathrm{Fe}_{2} \mathrm{O}_{3}\right.$, $\mathrm{TiO}_{2}$ ) in the raw materials. All test tubes are virtually insensitive to ammonium chloride solutions. These variations in mass allow us to say that our test pieces fired at $1280^{\circ} \mathrm{C}$ are less resistant to alkalis than to concentrated acids.

The $\mathrm{pH}$ of each solution before and after use was measured and recorded in Table 6. After chemical attack, no reduction in size of the specimens was observed with the naked eye. This could be explained by an unfinished reaction because many reactions start with intergranular attacks. Usually reactions at an early stage of attack can be detected using a light microscope. We can say that the test pieces did not undergo a great modification after the 12 days of immersion in concentrated chemical solutions $\left(100 \mathrm{~g} / \mathrm{L}\right.$ for $\mathrm{NH}_{4} \mathrm{Cl}$ and $\mathrm{KOH}$ and $18 \%$ for $\mathrm{HCl}$ ) and weakly concentrated $(30 \mathrm{~g} / \mathrm{L}$ for $\mathrm{KOH}$ and $3 \%$ for $\mathrm{HCl})$. These specimens are of class A.

\section{Discussion}

A higher muscovite content acts as a flux and forms a viscous liquid phase at the firing temperature. The densification of porcelain is essentially motivated by the gradual fusion of muscovite and quartz. According to the chemical composition of raw materials in Table 3, porcelain is constituted by alkaline $(\mathrm{Na}, \mathrm{K})$ and alkaline earth $(\mathrm{Mg}, \mathrm{Ca})$ elements. Those elements act as a flux during sintering, aiding densification and consequently reducing the porosity of the final product [29]. According to B. Tarhan et al. (2017) the mixed alkali effect, wherein different alkali ions are present at the same time, causes a decrease in the viscosity with initial replacement of $\mathrm{Na}_{2} \mathrm{O}$ by $\mathrm{K}_{2} \mathrm{O}$ [30]. The mixed alkali effect contributes to extending the glass working range. According to C.M.F. Vieira et al. (2004), fluxes are raw materials with a high amount of alkaline oxides, mainly $\mathrm{K}_{2} \mathrm{O}$ and $\mathrm{Na}_{2} \mathrm{O}$, which, in reaction with silica and alumina, promote liquid phase formation that facilitates the densification. The liquid phase surrounds the solid particles and by surface tension enables the particles approach, closing the porosity [31] [32].

In addition, firing at temperatures above $1240^{\circ} \mathrm{C}$ improves mechanical strength. Muscovite and illite are mica minerals that contain potassium. Theoretically, a high potassium content can lead to the superposition of a large amount 


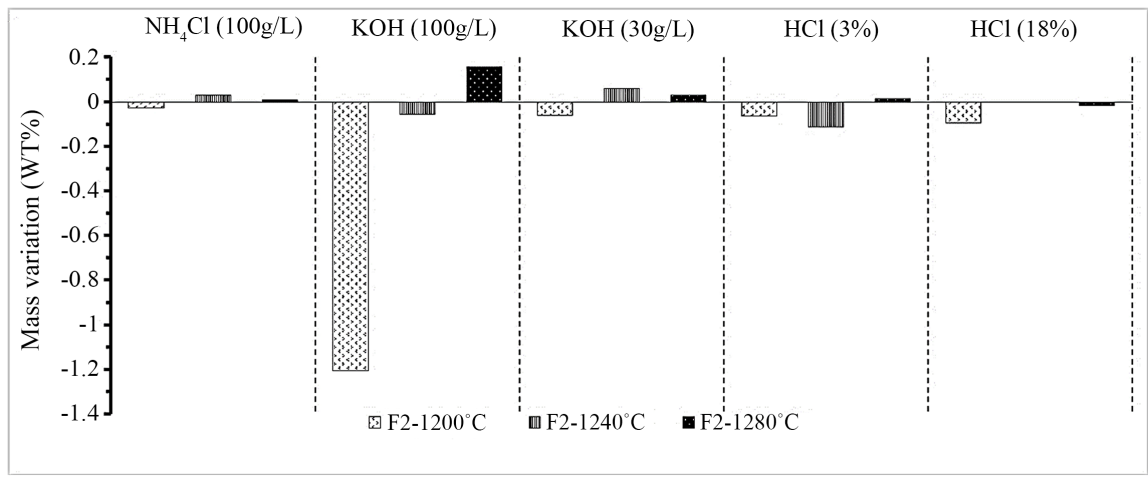

Figure 7. Histograms of variation in mass of test specimens subjected to chemical durability.

of melt to the formation of mullite in the clay-based ceramic bodies rich in illite. Lecomte et al. (2007) studied the influence of muscovite on the thermal transformation of kaolinite from room temperature to $1100^{\circ} \mathrm{C}$ [33]. They pointed out that the interaction of muscovite and kaolinite at temperatures above $900^{\circ} \mathrm{C}$ was mainly correlated with the diffusion of potassium ions from muscovite platelets into the structure of metakaolinite. Diffusion of potassium ions into the metakaolinite structure facilitated early crystallization $\left(1050^{\circ} \mathrm{C}\right)$ of mullite and the growth of mullite needles [27].

Linear shrinkage, water absorption, density change with temperature. We observe the same trends on the one hand with $\mathrm{F}_{1}$ and $\mathrm{F}_{3}$ and on the other hand with $\mathrm{F}_{2}$ and $\mathrm{F}_{4}$. The mechanical resistance increases overall with the temperature but it is dependent on the amount of alkali metal oxide. The particular changes in density, water absorption, porosity and flexural strength of $\mathrm{F}_{2}$ can be explained by the fact that its raw material contains significant concentrations of alkaline oxides $\left(\mathrm{Na}_{2} \mathrm{O}+\mathrm{K}_{2} \mathrm{O}\right)$ but also in iron oxide $\mathrm{Fe}_{2} \mathrm{O}_{3}$. Although iron oxide gives a brown color to the final product, it contributes to the formation of a glassy phase. The presence of these oxides explains the better fusibility of $F_{2}$ from $1240^{\circ} \mathrm{C}$. The particle size ratio $(\varphi>40 \mu \mathrm{m} / \varphi \leq 40 \mu \mathrm{m})$ of the starting raw materials could explain the gresification behavior (change in density, porosity, etc.) and the mechanical resistance of $F_{2}$. Compared with other shades, this ratio is 0.44 for $\mathrm{F}_{2}$ that is relatively high and indicates a more or less homogeneous character of the grains making up the specimen before cooking.

The diagram (Figure 5 and Figure 6) of diffraction of X-rays showed that intensities of mullite peaks are relatively low. The report that has fact is that by increasing the quantity of NONG clay, we observe an increase in the intensities of mullite peaks while those of quartz peaks decreased. An optimum temperature and composition at which considerable amounts of quartz and mullite crystals exist in the glass phase. This would maximize physical, mechanical and dielectric properties [34].

From the graph shown in Figure 8, we see that for all experimental temperatures in the boxed zone with $55 \%$ kaolinitic clay, $25 \%$ pegmatite and $20 \%$ sand as 


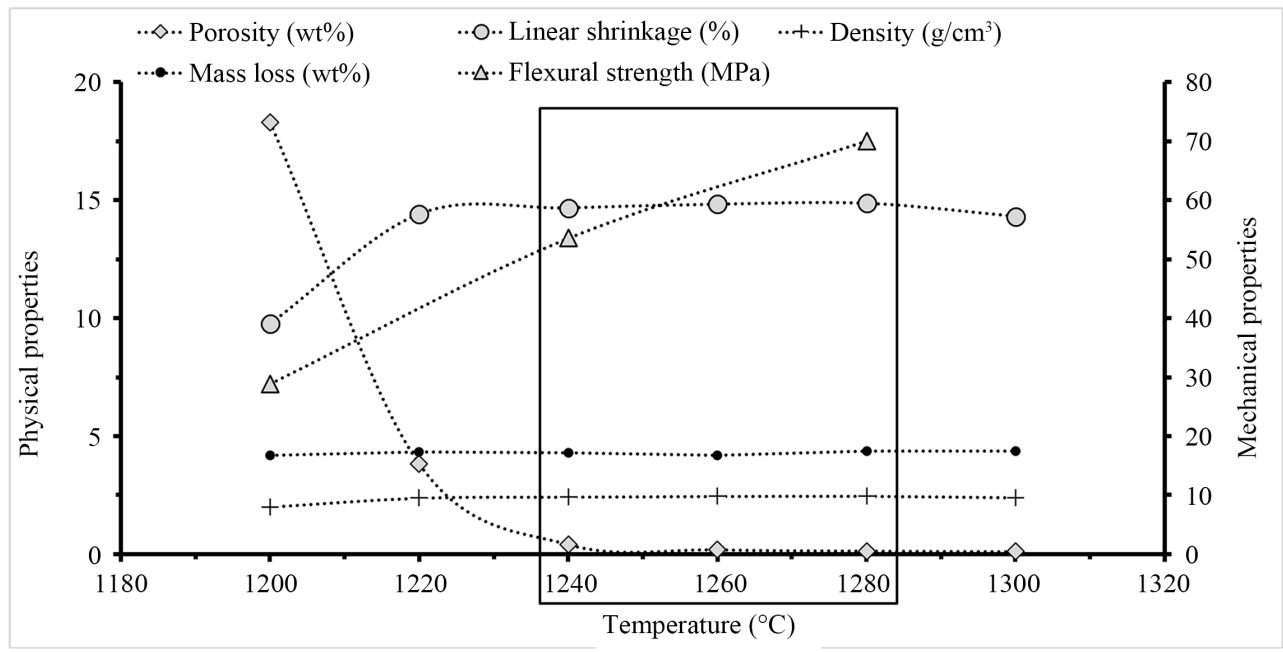

Figure 8. Determination of ideal firing temperature for grade $\mathrm{F}_{2}$.

raw materials. At these sintering temperatures, materials with interesting characteristics are obtained. We believe that the temperature $1240^{\circ} \mathrm{C}$ of this zone is the optimum firing temperature because the lowest therefore requires the minimum of energy during sintering.

The use of this composition is in agreement with the combination made by Y.M. Chiang et al. (1997) in the ternary diagram giving a mixture of mulite, quartz and liquid to the final product firing at $1300^{\circ} \mathrm{C}$ [35]. In this work, temperature of $1240^{\circ} \mathrm{C}$ gives a good compromise for all the technological parameters measured. It makes it possible to avoid a water absorption rate greater than $0.5 \%$, to have maximum mechanical performance ( $\geq 35 \mathrm{MPa}$ ), a loss of mass during cooking (between $4 \%$ and $4.5 \%$ ) and an acceptable linear shrinkage $(<15 \%)$ after baking.

According to Abeer A. El-Fallal et al. (2008) the presence of leucite cristalline phase has been shown to improve the mechanical properties [36]. In our work, the significantly higher flexural strength can be attributed to the presence of mica cristalline phases.

Factors such as the chemical composition, microstructure, porosity and surface texture of ceramics, regulate the resistance of the product to chemical attack. Durability is defined as the resistance to the attack of glass by water and aqueous solutions. The first stage of glass corrosion was previously represented by the ion exchange between alkali ions in the glass and hydrogen ions in the water [28]. However, Ernsberger (1980) suggests that chemical attack proceeds by the inward diffusion of water molecules which react with nonbridging oxygen atoms to form hydroxyl ions that diffuse out with the alkali ions to maintain electrical neutrality [37].

$\mathrm{pH}$ of the solutions used (Table 6) for the chemical attacks not known of significant variations. That shows that the porcelains are inert vis-a-vis the chemicals. The resistance to acid and basic attacks of our porcelains could be explained by the presence of a mixture potassium and sodium oxides in our raw materials. 
Table 6. $\mathrm{pH}$ of the solutions before and after use.

\begin{tabular}{cccccc}
\hline Solutions & $\mathrm{HCl}(18 \%)$ & $\mathrm{KOH}(100 \mathrm{~g} / \mathrm{L}) \mathrm{NH}_{4} \mathrm{Cl}(100 \mathrm{~g} / \mathrm{L})$ & $\mathrm{HCl}(3 \%)$ & $\mathrm{KOH}(30 \mathrm{~g} / \mathrm{L})$ \\
\hline $\mathrm{pH}$ before & 0.39 & 12.82 & 3.03 & 0.84 & 11.68 \\
$\mathrm{pH}$ after & 0.42 & 13.00 & 3.10 & 0.46 & 10.30 \\
\hline
\end{tabular}

This observation was made by K. J. Anusavice (1992) according to which, the chemical durability of glasses made with potash $\left(\mathrm{K}_{2} \mathrm{O}\right)$ is approximately half that of glasses made with soda $\left(\mathrm{Na}_{2} \mathrm{O}\right)$, presumably because of the difference in ionic size. According to the same author a mixed alkali effect occurs when both $\mathrm{Na}$ and $\mathrm{K}$ are present, such as is often the case with feldspathic porcelains [28].

\section{Conclusion}

Porcelains obtained with different grain sizes and raw material contents have varied physicochemical and mineralogical properties. These properties are linked not only to the nature, to the size of grains and to the proportions of raw materials used, but also to the cooking temperature. Various results have shown that the porcelain specimens made with $50 \%$ to $65 \%$ kaolinitic clays from Nongfaïré, $25 \%$ to $20 \%$ pegmatite from Kotédougou and $25 \%$ to $15 \%$ sand from Bobo and sintered between $1240^{\circ} \mathrm{C}-1280^{\circ} \mathrm{C}$ have characteristics which are consistent with those in the literature. The role of $\mathrm{Na}$ and $\mathrm{K}$ cations, is to decrease the melting temperature of the glass batch and favor the melting of other minerals that are presented in the formulation. These results indicate that the rates of the fluxes alone should not be used as an argument to explain the evolution of the parameters in the optimization of the contents. But it is necessary to take into account the proportions of the sizes of the grains of the powders of raw materials as well as all the sources that can contribute to the formation of vitreous phases. Grade of 55\% kaolinite clay, 25\% pegmatite and 20\% sand was chosen as the optimum content for the production of porcelain with an optimum temperature of $1240^{\circ} \mathrm{C}$. Finally, it was concluded that post sintering porcelains to use in its composition in case of commercial production and it was better to keep the firing temperature around $1240^{\circ} \mathrm{C}$ or as lower as possible.

\section{Conflicts of Interest}

The authors declare no conflicts of interest regarding the publication of this paper.

\section{References}

[1] Yilmaz, S. and Engin Erkmen, Z. (2007) Creep of Hard Porcelain during Firing. American Ceramic Society Bulletin, 86, 9301-9034.

[2] Carty, W.M. and Senapati, U. (1998) Porcelain-Raw Materials, Processing, Phase Evolution and Mechanical Behavior. Journal of the American Ceramic Society, 81, 3-20. https://doi.org/10.1111/j.1151-2916.1998.tb02290.x

[3] Sawadogo, Y., Zerbo, L., Sawadogo, M., Seynou, M., Gomina, M. and Blanchart, P. 
(2020) Characterization and Use of Raw Materials from Burkina Faso in Porcelain Formulations. Results in Materials, 6, Article ID: 100085. https://doi.org/10.1016/j.rinma.2020.100085

[4] Carty, W.M. (2001) Rheology and Plasticity for Ceramic Processing. In: Smith, J. and Bennett, J., Eds., Fundamentals of Refractory Technology, Vol. 125, American Ceramic Society, Westerville, 29-52. https://doi.org/10.1002/9781118370940.ch2

[5] Mostari, S. and Haque, J. (2020) Recycling of Post Sintered Sanitaryware Waste in Its Formulation. International Journal of Technical Research \& Science, 5, 27-34. https://doi.org/10.30780/IJTRS.V05.I08.004

[6] Martin-Marquez, J., Rincon, J.M. and Romero, M. (2008) Effect of Firing Temperature on Sintering of Porcelain Stoneware Tiles. Ceramics International, 34, 1867-1873. https://doi.org/10.1016/j.ceramint.2007.06.006

[7] International Organization for Standardization (1995) Norme ISO 10545-3. Détermination de l'absorption d'eau, de la porosité ouverte, de la densité relative apparente et de la masse Volumique Globale.

[8] International Organization for Standardization (2015) ISO 10545-13. Ceramic Tiles, Determination of Chemical Resistance.

[9] Seynou, M., Flament, P., Sawadogo, M., Tirlocq, J. and Ouedraogo, R. (2013) Refractory Bricks Based on Tikaré (Burkina Faso) kaolinitic Raw Clay Material. Journal de la Société Ouest-Africaine de Chimie, 35, 49-56.

[10] Zerbo, L., Seynou, M., Sorgho, B., Lecomte-Nana, G., Gomina, M. and Blanchart, P. (2019) Microstructure and Weibull Distribution of Rupture Strength of Clay-Talc ceramics. Cerâmica, 65, 240-245. https://doi.org/10.1590/0366-69132019653742518

[11] Abdullaeva, M., Murzubraimov, B., Altybaeva, D., Abdullaeva, Z., Kalykova, G., Suiunbekova, A. and Osmonova, A. (2021) Investigation of Pegmatite Mineral Applicability from the Terek Ceramic Deposit in Kyrgyzstan for Production of Porcelain and Earthenware. Journal of Minerals and Materials Characterization and Engineering, 9, 169-179. https://doi.org/10.4236/jmmce.2021.92012

[12] Yates, J.D. and Lombardo, S.J. (2002) Strain Mismatch and Deformation of Slip Cast Alumina Bodies: The Effects of Solids Loading, Dispersant Concentration, and Binder Concentration. In: Carty, W.M., Ed., Materials \& Equipment/Whitewares: Ceramic Engineering and Science Proceedings, Vol. 23, American Ceramic Society, Ohio, 1-14. https://doi.org/10.1002/9780470294734.ch1

[13] Zanelli, C., Raimondo, M., Guarini, G. and Dondi, M. (2011) The Vitreous Phase of Porcelain Stoneware: Composition, Evolution during Sintering and Physical Properties. Journal of Non-Crystalline Solids, 357, 3251-3260.

https://doi.org/10.1016/j.jnoncrysol.2011.05.020

[14] Wimuktiwan, P., Rodchom, M., Soongprasit, K., Atong, D. and Vichaphund, S. (2020) Influence of the Addition of Pore Foaming Agent on Mechanical and Thermal Properties of Porcelain Tiles. Ceramics-Silikáty, 64, 164-171. https://doi.org/10.13168/cs.2020.0005

[15] Kamseu, E., Leonelli, C., Boccaccini, D.N., Veronesi, P., Miselli, P., Pellacani, G., et al. (2007) Characterisation of Porcelain Compositions Using Two China Clays from Cameroon. Ceramics International, 33, 851-857. https://doi.org/10.1016/j.ceramint.2006.01.025

[16] Mustafi, S., Ahsan, M. and Dewan, A.H. (2008) Effect of Particle Size of Quartz on Bending Strength of Porcelain. Bangladesh Journal of Scientific and Industrial Research, 43, 537-544. https://doi.org/10.3329/bjsir.v43i4.2244 
[17] Yahya, H., Abdul Mois, A.R. and Ahmad, A. (2018) Fabrication and Characterization of Anorthite-Based Porcelain using Malaysian Mineral Resources. International Journal of Current Science and Technology, 1, 106-111.

[18] Iqbal, Y. and Lee, W.E. (2000) Microstructural Evolution in Triaxial Porcelain. Journal of the American Ceramic Society, 83, 3121-3127. https://doi.org/10.1111/j.1151-2916.2000.tb01692.x

[19] Iqbal, Y. (2008) On the Glassy Phase in Tri-Axial Porcelain Bodies. Journal of Pakistan Materials Society, 2, 62-71.

[20] Taylor, J.R. and Bull, A.C. (1986) Ceramics Glaze Technology. Pergamon Press, New York, 150.

[21] Amrane, B., Ouedraogo, E., Mamen, B., Djaknoun, S. and Mesrati, N. (2011) Experimental Study of the Thermo-Mechanical Behaviour of Alumina-Silicate Refractory Materials Based on a Mixture of Algerian Kaolinitic Clays. Ceramics International, 37, 3217-3227. https://doi.org/10.1016/j.ceramint.2011.05.095

[22] Martin-Marquez, J., De la Torre, A.G., Aranda, M.A.G., Rincon, J.M. and Romero, M. (2009) Evolution with Temperature of Crystalline and Amorphous Phases in Porcelain Stoneware. Journal of the American Ceramic Society, 92, 229-234. https://doi.org/10.1111/j.1551-2916.2008.02862.x

[23] Wattanasiriwech, D. and Wattanasiriwech, S. (2011) Fluxing Action of Illite and Microcline in a Triaxial Porcelain Body. Journal of the European Ceramic Society, 31, 1371-1376. https://doi.org/10.1016/j.jeurceramsoc.2011.01.025

[24] International Organization for Standardization (2019) EN ISO 10545-4. Ceramic Tiles-Part 4: Determination of Modulus of Rupture and Breaking Strength.

[25] Ke, S., Cheng, X., Wang, Y., Wang, Q. and Wang, H. (2013) Dolomite, Wollastonite and Calcite as Different $\mathrm{CaO}$ Sources in Anorthite-Based Porcelain. Ceramics International, 39, 4953-4960. https://doi.org/10.1016/j.ceramint.2012.11.091

[26] Kr Das, S. and Dana, K. (2003) Differences in Densification Behaviour of K- and Na-Feldspar-Containing Porcelain Bodies. Thermochimica Acta, 406, 199-206. https://doi.org/10.1016/S0040-6031(03)00257-0

[27] Romero, M., Padilla, I., Contreras, M. and López-Delgado, A. (2021) Mullite-Based Ceramics from Mining Waste: A Review. Minerals, 11, Article No. 332. https://doi.org/10.3390/min11030332

[28] Anusavice, K.J. (1992) Degradability of Dental Ceramics. Advances in Dental Research, 6, 82-89. https://doi.org/10.1177/08959374920060012201

[29] Dal Bó, M., Dominguini, L., Zimmer, A., Grando, S.R., Kaspari, P. and Hotza, D. (2016) Chemical Tempering of Porcelain Tiles. Ceramics International, 42, 15199-15202. https://doi.org/10.1016/j.ceramint.2016.06.138

[30] Tarhana, B., Tarhan, M. and Aydin, T. (2017) Reusing Sanitaryware Waste Products in Glazed Porcelain tile Production. Ceramics International, 43, 3107-3112. https://doi.org/10.1016/j.ceramint.2016.11.123

[31] Vieira, C.M.F., Soares, T.M., Sánchez, R. and Monteiro, S.N. (2004) Incorporation of Granite Waste in Red Ceramics. Materials Science and Engineering A, 373, 115-121. https://doi.org/10.1016/j.msea.2003.12.038

[32] Fuertes, V., Reinosa, J.J., Fernandez, J.F. and Enríquez, E. (2022) Engineered Feldspar-Based Ceramics: A Review of Their Potential in Ceramic Industry. Journal of the European Ceramic Society, 42, 307-326. https://doi.org/10.1016/j.jeurceramsoc.2021.10.017

[33] Lecomte, G.L., Bonnet, J.P. and Blanchart, P. (2007) A Study of the Influence of 
Muscovite on the Thermal Transformations of Kaolinite from Room Temperature up to $1100^{\circ} \mathrm{C}$. Journal of Materials Science, 42, 8745-8752.

https://doi.org/10.1007/s10853-006-0192-7

[34] Olupot, P.W. (2006) Assessment of Ceramic Raw Materials in Uganda for Electrical Porcelain. Licentiate Thesis in Material Science, Department of Materials Science and Engineering, Royal Institute of Technology (KTH) Stockholm, Stockholm.

[35] Chiang, Y.M., Burnie III, D. and Kingery, W.D. (1997) Physical Ceramics: Principles for Ceramic Science and Engineering. John Wiley, New York, 342-344.

[36] El-Fallal, A.A., Hassan, A.M., Hamouda, I.M. and El-Wassefy, N.A. (2008) Evaluation of Newly Developed Egyptian Low-Fusing (Leucite) Dental Porcelain. Journal of Biophysics and Biomedical, 1, 98-103.

[37] Ernsberger, F.M. (1980) The Role of Molecular Water in the Diffusive Transport of Protons in Glasses. Physics Chem Glasses, 21, 146-149. 